\title{
sciendo
}

\section{Information System for Medicinal and Aromatic Plants Value Chain: Case Study of Albania}

\author{
Julian Lekoçaj \\ Faculty of Forestry, Agricultural University of Tirana, Tirana, Albania \\ Valter Hoxha \\ Faculty of Economy, Mediterranean University of Albania, Tirana, Albania
}

\section{Abstract}

Background: Medicinal and Aromatic Plants (MAPs) are part of a few products that Albania exports in World's level. The results showed us that the available MAPs value chain information in Albania through several cases is limited and doesn't match with reality. Objectives: Our research aims to verify the actual situation of the information system between the actors of the MAPs value chain in Albania. Methods/Approach: In this research is used the systemic method, which takes into consideration the analysis through all the main value chain links. For each value of the chain links has been selected a statistical representation number or a sample. Results: The actors that operate through the MAPs market in Albania are in front of the asymmetric information. The sources and the methods used are not on the proper level to offer the real results in this value chain. There are many information system sources for the Albanian MAPs sector, but none of them offers any detailed data about the quantity and the value on plant's level. Conclusions: The information system of the MAPs value chain is not functional through all the links, while the fabrication still remains on limited levels. The creation of a monitoring system database in time and space for the entire MAPs sector is a necessity.

Keywords: medicinal and aromatic plants, market, asymmetric information, value chain, information system sources

JEL classification: O30, D83, 121

Paper type: Research article

Received: Dec 5, 2018

Accepted: Jan 24, 2019

Citation: Lekoçaj, J., Hoxha, V., (2019), "Information System for Medicinal and Aromatic Plants Value Chain: Case Study of Albania" Business Systems Research, Vol. 10 No. 1, pp. 31-41.

DOI: $10.2478 / \mathrm{bsrj}-2019-0003$

\section{Introduction}

Albania has a rich variety of medicinal and aromatic plants (MAPs) due to its favorable climate and geographic position. The complete inventory realized in 1987 from the government institutions shows that the Albanian territory has a capacity of around 213,000 tons (Llubani, 1988; Hoxha, 2016). MAPs represent a very important sector in the Albanian economy, and Albania ranks the 16th in 
exporting MAPs in the world with an amount of 7277 tons per year (COMTRADE, 2018). Figure 1 below shows the ranking of Albania export in the World for the MAPs exports at the end of 2017. The country has lost two positions compared to the export volume in 2014 (llbert and Hoxha, 2016).

Figure 1

The rank of Albania for the MAPs exports at the end of 2017 according to netweight (tons)

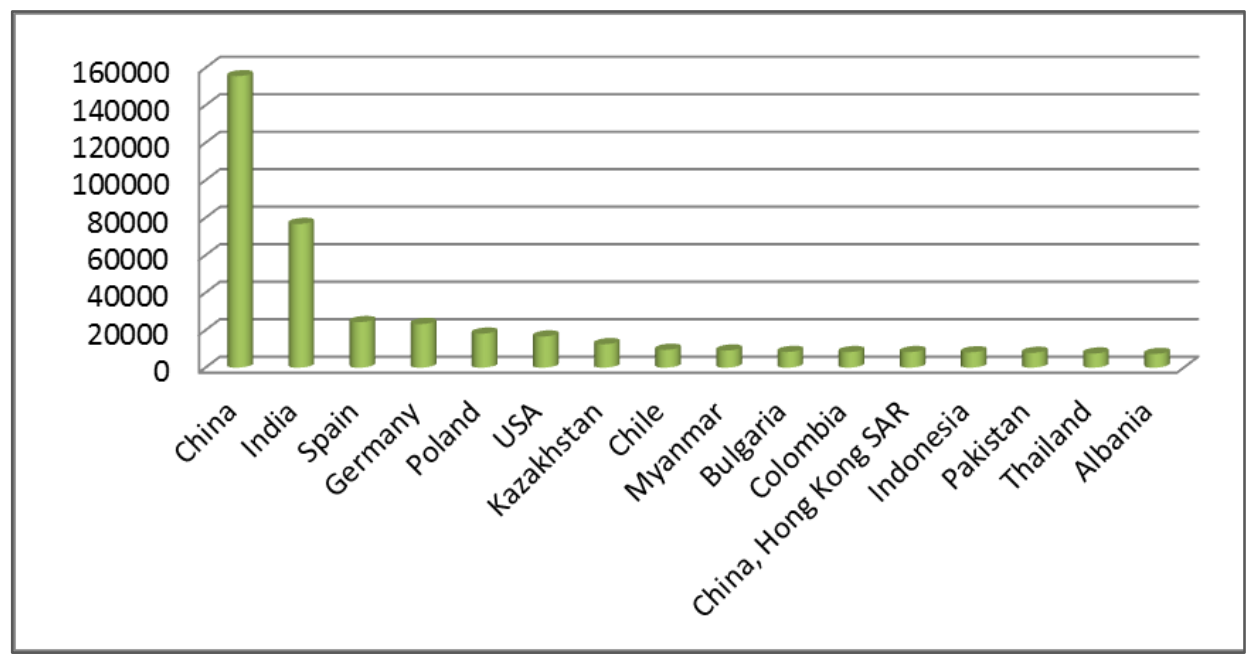

Source: Authors' work based on COMTRADE official database (2018)

According to some national studies, this sector plays a very important socioeconomic role. It employs between 70.000 and 100.000 low-income farmers who live in the marginalized hilly and mountainous areas (Noka and Musabelliu, 2003; USAID, 2010) thus contributing to a large portion of the income of their households (Paul, 2014). The MAPs sector is a very important item (in monetary value) in the balance sheet and one of the most important products exported from Albania. Based on the statistics of the Agricultural Ministry and Rural Development, the Albanian MAPs sector represents more than half of the total agricultural exports, compared with the farming and agro-industry sectors. In 2017, this export amounted around $\$ 17$ million or about $16 \%$ of total agricultural exports (Lekocaj et al., 2017).

Figure 2

The MAPs Albanian exports, period 1996-2017

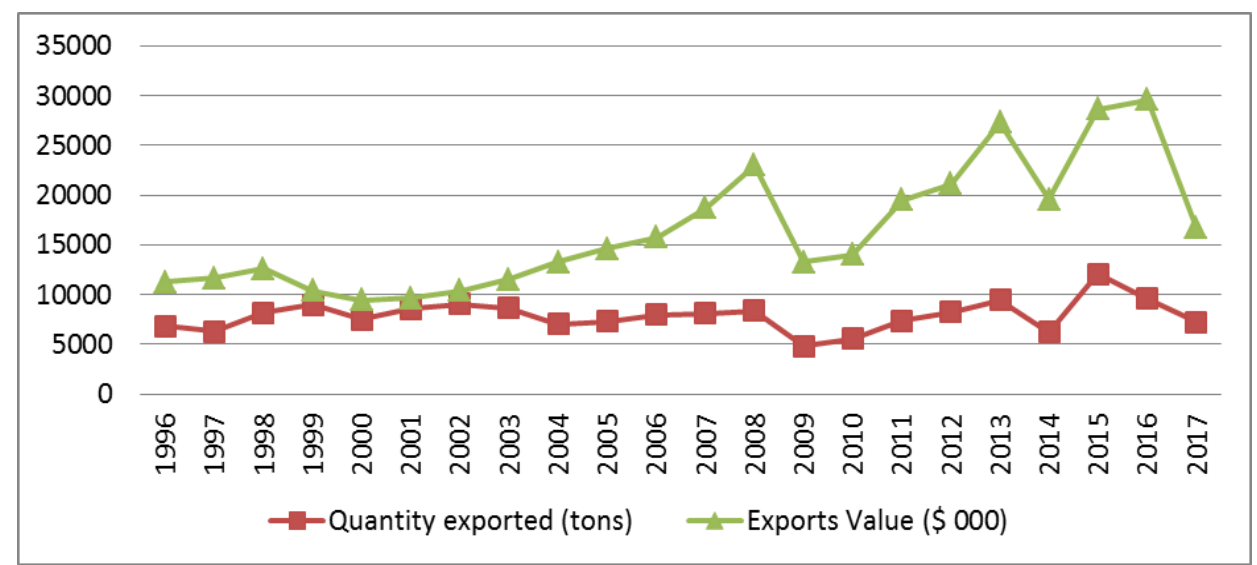

Source: Authors' work based on COMTRADE official database (2018) 
According to COMTRADE (2018) statistics (Figure 2), we see that the trend of MAPs exports has little variation. The exports average remains between 7500 tons/year. In contrary, in monetary value, it is shown that in 2008 we have a constant increase of around \$23 million, and in 2009a strong decline of \$17 million. After the financial crisis in 2008, we see that the market experiences a strong rise and fall fluctuations, wherein in 2016 it reaches $\$ 30$ million, but in 2017, it flops again to $\$ 17$ million.

Economic theories give different explanations and reasoning for the market's problem and performance. They can derive from the market structure or from the sector operation mode, or from the company strategies that are directly linked with the available information by their administrators (Reference). So the lack of information or the asymmetric information makes that the economic agents will have limited rationality toward their decision. The neo-Keynesian theory emphasizes that markets are inefficient due to the lack of transparency. Economic agents have limited rationality because of asymmetric information. The asymmetry of this information leads agents to the selection of unsatisfactory products such as the case study studied by Akerlof (1970) or Insurance Contracts published by Rothschild and Stiglitz (Rothschild and Stiglitz, 1970).

In the Albanian MAPs sector case, the lack of information problem is identified by many studies. According to a USAID study in 2010, "The Albanian statistics are not very reliable, and it is impossible to obtain detailed data on export by type of MAP. So data provided by INSTAT are only at an aggregated level, and it is not possible to obtain reliable data at the product level (i.e., sage)", this information is not reliable (USAID, 2010, p. 1). In 2015 another study was done by the French Agricultural Ministry MAPs sector which identifies the lack of information through all the value chain links (Hoxha, 2016).

Seen in this context, this study aims to analyze in details the information system, channeling and the fabrication of the MAPs sector in Albania.

\section{Methodology}

To achieve our objectives, we use a systematic approach. This method gives us the opportunity to see the interactions between the elements that produce and offer information. Through this method, we want to identify the main sources of information production and the reason why this information is not complete and accurate.

We classified the main sources of information into 5 levels (Figure 3). For the first level, we searched for the information, which can be found through the international organization's database like Eurostat, UN COMTRADE, or even from the countries that import MAPs from Albania. 
Figure 3

The information system scheme for the MAPs value chain in Albania

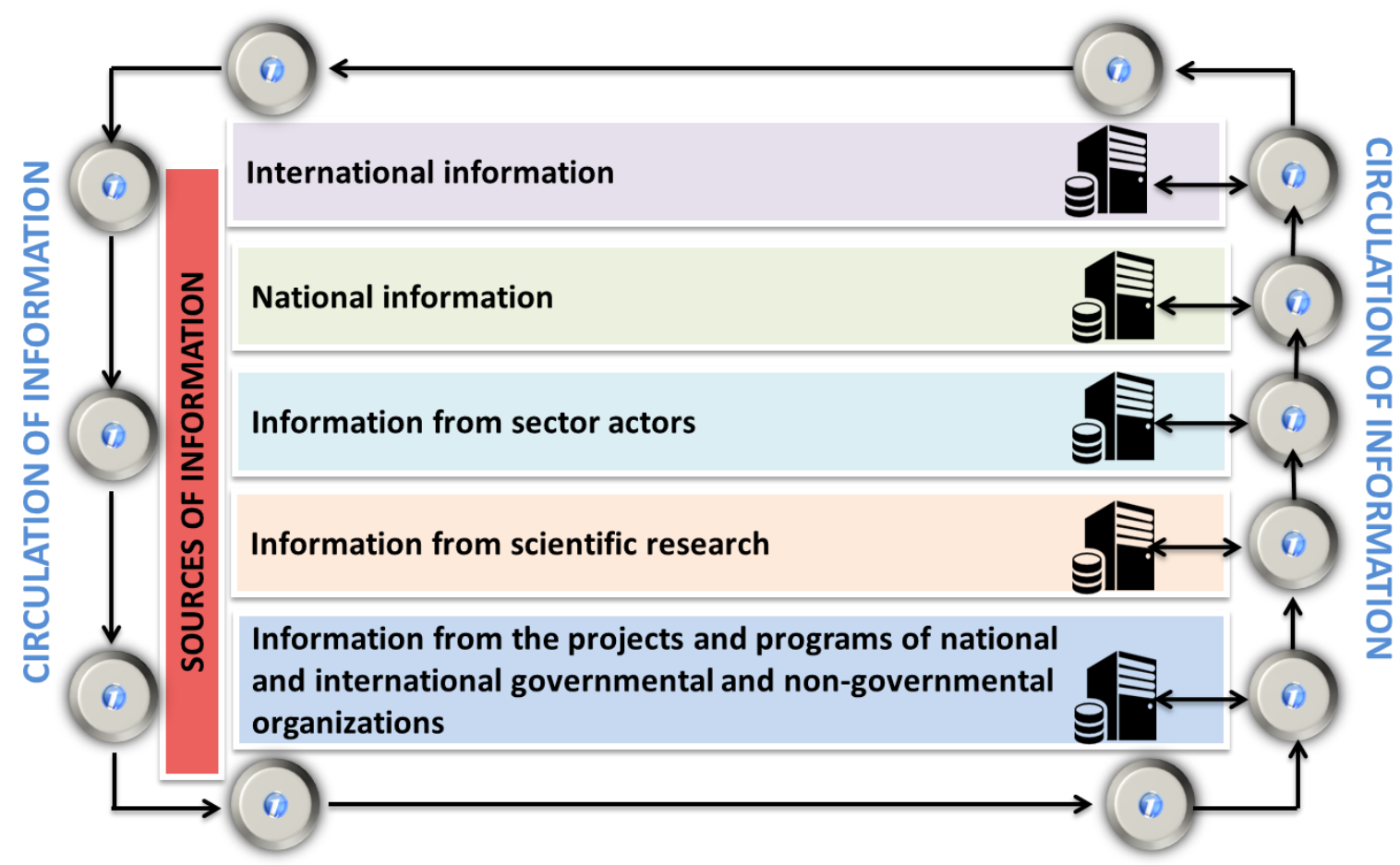

Source: Authors' illustration

For the second level, we searched the information that is offered by the government institutions database, such as Ministries, the statistics institution in the center and the municipalities in localities. For that, we chose three regions that have a long tradition and great engagement in this sector and geographically represented three big parts of the Albanian territory (Figure 4). For the south part was chosen Vlora, for the north part Shkodra and Malesia e Madhe, for the eastcentral part Dibra. For every region, we chose the number of actors that would be interviewed. Therefore, for the MAPs fund administration, we went to each of the respective municipalities.

For the third level, we searched for the information that is offered by the value chain actors. In defining the surveyed actors, we were based on the value chain approach. This method is widely used for the Value Chain Analysis (VCA) or for the asset's general theory (Kaplinsky and Morris, 2001) and by many international organizations for the agro-food value chain analysis. In the beginning, we identified the main actors of every value chain's link. For the exporters' link, we choose to interview most potential ones, (who are actually piloting the MAPs value chain) in order that our records could be as reliable as possible (Figure 5).

As below, in figure 5 we have featured the main exporters for period 2015-2016 by ranking them according to the USAID study realized in 2010. Between them, we chose five leading companies as Gjedra Company, Filipi Company, Elba Shehu Company, Mucaj and Xherdo Company. For the MAPs harvesters, we decided to interview 30 (thirty) people for each region. 
For the fourth level, we searched for the information that is offered by the researching institutions databases in Albania. For the last level, we put the information produced by other studies realized from national and international organizations (on a nongovernmental organization level).

Figure 4

Areas of study

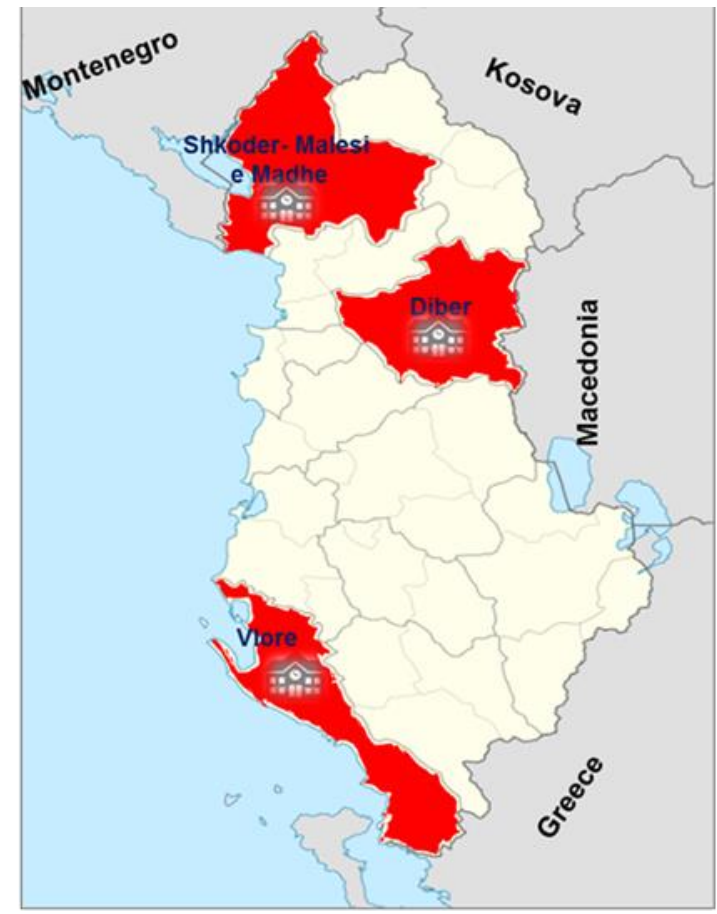

Source: Authors' illustration
Figure 5

Interviewed actors

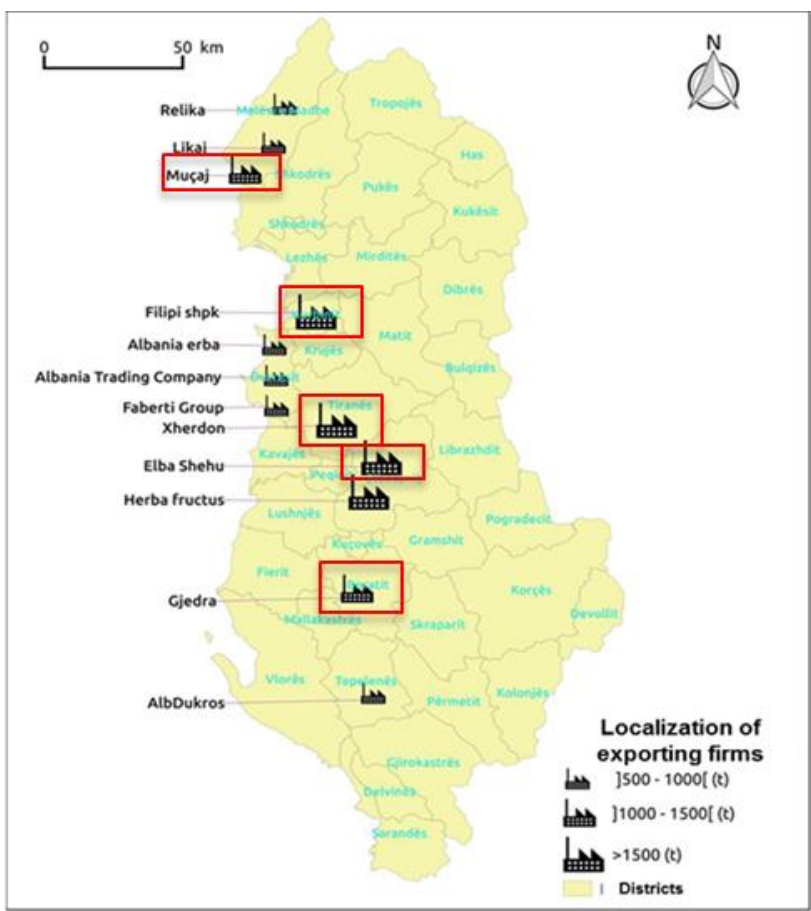

Source: Hoxha (2016)

\section{Results}

Based on our research, we mapped the main actors where the information MAPs value chain is produced and manufactured (Figure 6). The Figure shows the information channels between the actors that work and are interested in the MAPs exploitation, protection, and management.

The results show that there exist two types of actors that take place setting up and developing the MAPs value chain system information in Albania.

One group offers factual data based on the value chain actor's activity, which are the direct actors and the institutions that register these statistics. In the other group, we have the actors that try through the scientific research and different projects to improve this information contributing to the methodological improvement and the information infrastructure. 
Figure 6

The MAPs value chain information sources and its circulation in Albania

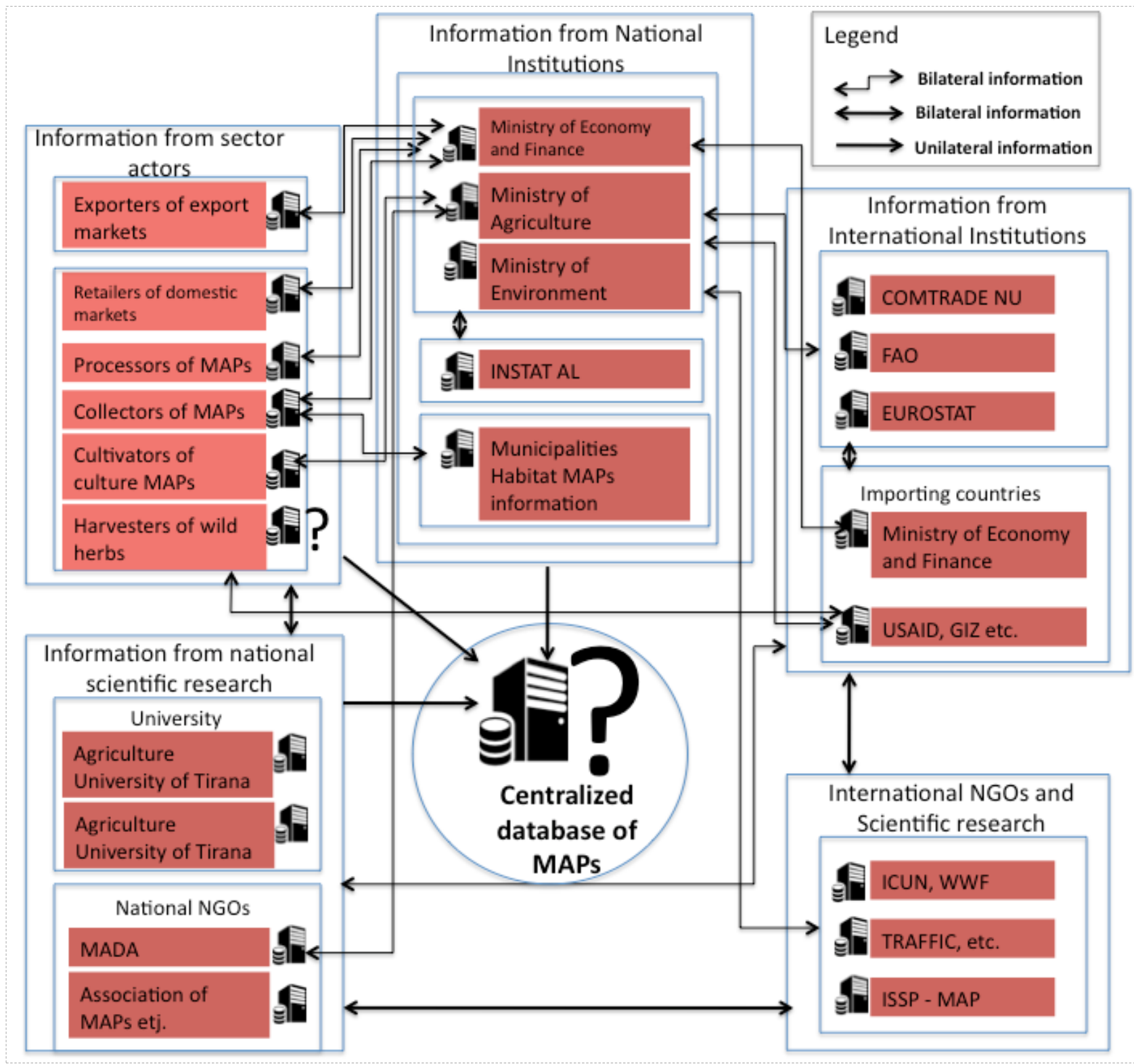

Source: Authors' illustration

In the first group: the international institutions level, the main organizations that offer information about the MAPs sector in Albania are the United Nations (UN) database statistics sUch as COMTRADE and EUROSTAT. As shown in figure 7, the COMTRADE database except for some plants offers information in quantity and value for the MAPs group (selected commodities: 1211) at a general level. 
Figure 7

The Albanian MAPs data from the UN COMTRADE database (commodity HS 1211)

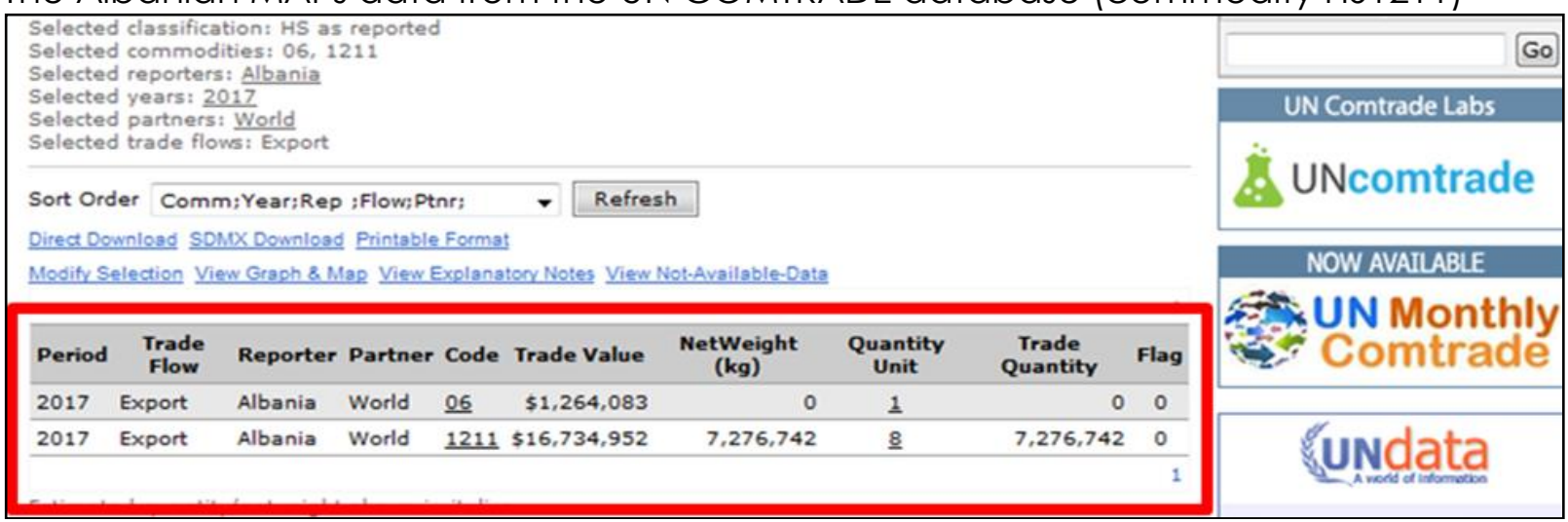

Source: Authors' illustration based on COMTRADE database (2018)

This data can also be found from the customs of the importing countries that Albania makes this trade (Table 1). These data are in aggregate or on a generalized level. Table 1 shows the import-export data between France and Albania, taken by the French Customs, which are the same as those of the COMTRADE database.

Table 1

The Albanian MAPs data import-export between France and Albania

\begin{tabular}{llllllcc}
\hline Comtrade 2015 & $\mathbf{2 0 1 4}$ & Import & $\mathbf{3 3 0 1}$ & France & Albania & $\mathbf{2 1 7 2 3 3}$ & $\mathbf{3 5 2 5}$ \\
\hline & & & & & & EUR \\
DOUANE FR 2015 & 2012 & Export & 1211 & France & Albania & 0 & 0 \\
DOUANE FR 2015 & 2013 & Export & 1211 & France & Albania & 1485 & 750 \\
\hline DOUANE FR 2015 & 2014 & Export & 1211 & France & Albania & 13559 & 12950 \\
DOUANE FR 2015 & 2012 & Import & 1211 & France & Albania & 1017297 & 520580 \\
DOUANE FR 2015 & 2013 & Import & 1211 & France & Albania & 922756 & 475952 \\
DOUANE FR 2015 & 2014 & Import & 1211 & France & Albania & 1199032 & 575686 \\
\hline
\end{tabular}

Source: Hoxha (2016)

On national level are included the governmental institutions such as the Ministry of Economy and Finance, the Ministry of Agriculture and the Ministry of Environment. The Ministry of Economy and Finance database is supplied by the Customs data (Figure 8) and the companies' activity balance sheets, which operate into the MAPs sector, (forced by the law to present their financial statements).

Figure 8

The Albanian MAPs data from the Albanian Ministry of Economy database

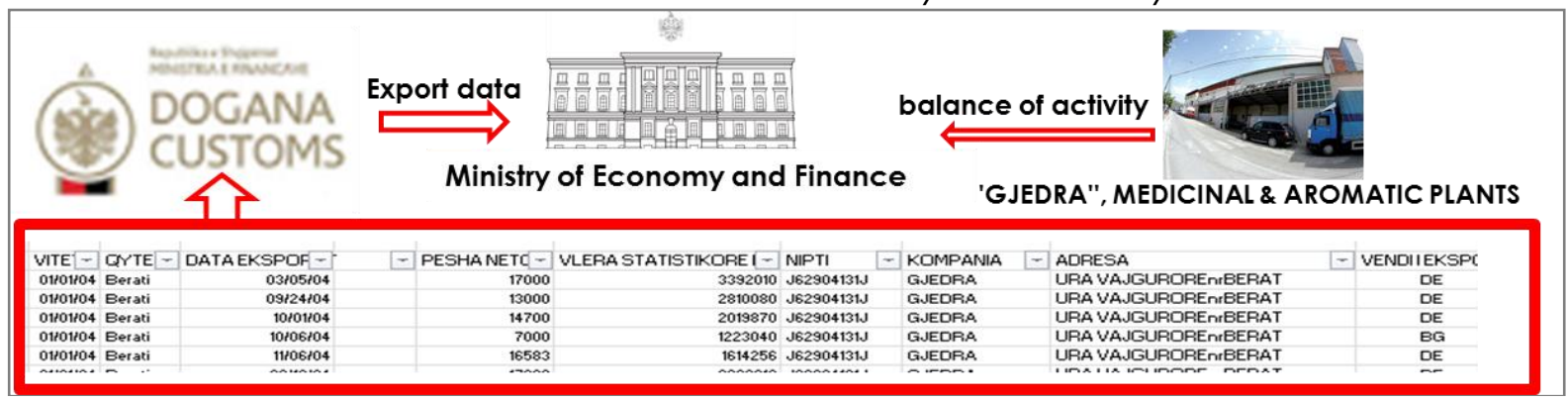

Source: Authors' illustration 
The Ministry of Environment must dispose of quantitative data about the capacity of these sources and geographic data about the surface of their habitats. In order to find this information, the specialists (foresters, botanists) use the spatial observation or the remote sensing method (Figure 9) and botanical sampling method (Figure 10).

Figure 9

The methods of remote sensing
Figure 10

Botanical sampling method

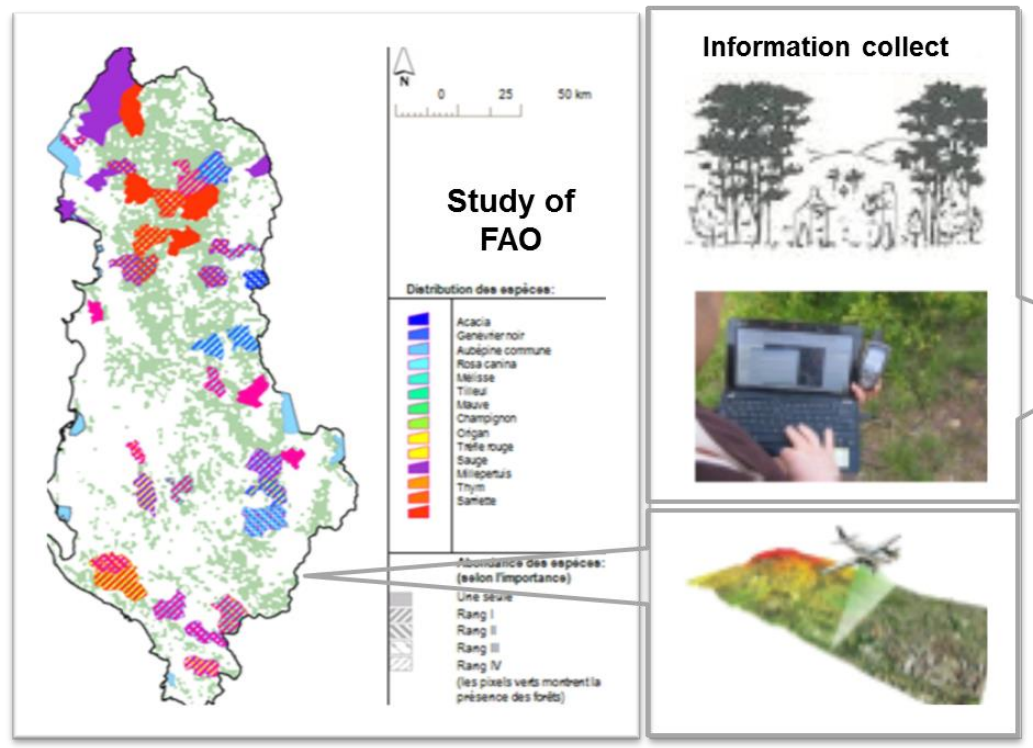

Source: Noka and Musabelliu (2003)

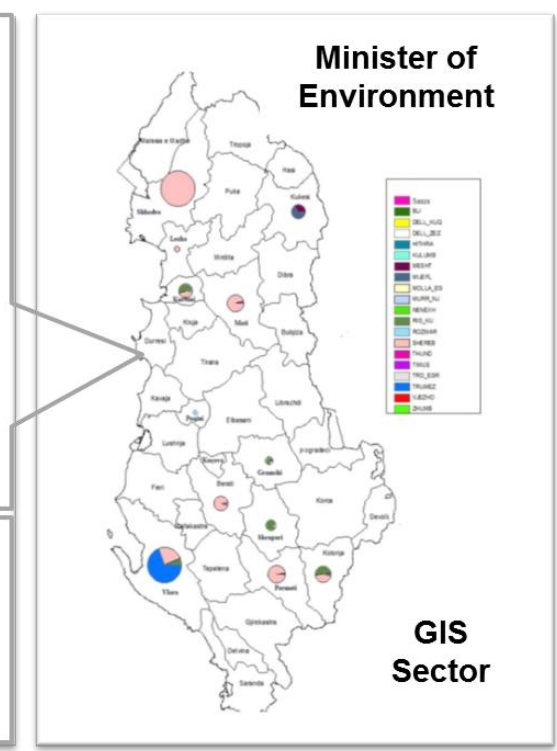

Source: Dano, et al. (2008)

The remote sensing and spatial observation methods (GIS), offer a great opportunity for the identification and management of the natural resource. Unfortunately, their applications in the case of MAPs have their limitations. Many species of MAPs are under crop canopy, and they are not directly visible by conventional remote sensing methods. In nature, they don't occupy particularly homogeneous surfaces. As for the botanical sampling method, even with these methods, we face some problems related to human resource needs as well as technical problems and financial ones (Hoxha and llbert, 2017).

The second method is the botanical inventory method which proceeds by samples. The plant's habitat knowledge is realized by the specialists (foresters, botanists) who operate via the floristic sampling of samples. An extrapolation is then carried out, as a function of the surface and the yields, in the whole predetermined territory (Kutrolli and Ukaj, 2009). This method has now been enriched with geographic tools such as GPS or GIS in order to better locate and observe the test samples (Dano et al., 2008). This method is called « Diagnosis and Design » (D\&D).

On the other side, the Ministry of Agriculture must obtain the data about the MAPs cultivated surfaces per year.

From our research, none of these two Ministries has full information, for either the spontaneous plants or the cultivated ones. The used methodologies for the inventories and these sources identification, the lack of human resources about specialists and financial sources complicates their job. In the value chain actors' level, those who dispose of data about the plants are the business-registered companies that have regular activity, such as collectors, processors, retailers of domestic markets and exporters (figure 5). From the realized interviews comes in 
evidence the difference between the export figures that are officially published from the Ministries, INSTAT and the exporters' data. The head of MAPs association, Mr. Filip Gjoka publicly declared that the MAPs exports reached about 45 million USD where from COMTRADE or Ministries statistics during the last years we have an average of about 25 million USD. Regarding the harvesters and MAPs culture cultivators, there does not exist any correct information, while their activity is not registered.

To improve this system information, there is the second group of actors, which are divided according to their aim of the foundation. Therefore, in an international level, we have the development agencies of developed countries such as USAID, $\mathrm{GIZ}$, etc., the researching institutions like Universities and the researching centers in this field, those of protection and plant trafficking, wherein an international level, we have UICN, WWF, TRAFFIC, and others.

Usually, the information found from COMTRADE and EUROSTAT is also found from FAO database, but this institution also contributes through several projects and programmes for the inventories methods improvement and the protection of these plants, cooperating with all the governmental, the researching and nongovernmental actors (NGO) (Noka and Musabelliu, 2003).

In a national level, the most important ones are the universities' researching centers like the Agriculture University of Tirana or University of Tirana, half public organizations like MADA (Mountain Area Development Agency), or different nongovernmental organizations where we can mention the MAPs association or EPCA (Essence Producers and Cultivators Association).

\section{Conclusion}

Our research revealed that the information system identification through a 360 grades specter about the MAPs value chain in Albania is very difficult. This happens because of the sector's nature, where in many cases, mostly for the processing and those of import-export companies, the information is considered an industrial secret (Ilbert and Hoxha, 2016). In the proposed scheme, we tried to put the main actors that inform or take part in the value chain identification and improvement. However, with no doubt, there will also remain other ones that contribute in this network like the geomatics researchers (Hoxha, 2014), or the natural resources management which is linked in an indirect way with these sources. Possibly, this is also one of our researching limits. Even, state institutions like the Ministry of Economy and Finance or the Ministry of Agriculture have a very important role in this valuechain information system. The technique and legal instruments that they dispose of can give more transparency, something that would help better the actors toward an efficient decision. In fact, this will remain part of an opened discussion.

The lack of information for the MAPs value chain in Albania has been relieved since 2010 from USAID (USAID, 2010) and it has been identified by other studies (Hoxha, 2016, Lekocaj et al. 2017). This problem hosted our researching question about the way that the information system works and which are its creation sources.

In our results, we identified two types of actors that give and help to create the information. In the first group, there are the actors who dispose of factual data from the harvesting up to the final sale. In addition, here take part all the companies that have a legal business and register everything on their balance sheets, while the state institutions control and verify their activity. The second group included the actors that contribute in an indirect way about the methods' improvement, their recognition instruments, the protection and the evaluation of these sources. 
To sum up or based on our data, we conclude that in the first group of actors exists a lack of information from the spontaneous plants' harvesters and from the cultivators (about the quantity and the geographic surface identification). Even from the other actors, we do not have full information regarding the statistics data, neither from the small collectors nor from the sellers in the local or foreign market.

We recommend collecting remoting sense data which can help in creating a monitoring system database for the entire MAPs sector, as outlined in Figure 5. Thus, it is crucial the utilization of the new methods to identify the used habitats, to identify the involved actors, as well as to give a clear picture of the value chain between the participating actors up to the final sale. This would directly contribute to the market transparency and on more rational decision-making use and trade these resources while giving them the opportunity to go toward qualitative products.

\section{References}

1. Akerlof, A. G. (1970), "The Market for "Lemons": Quality Uncertainty and the Market Mechanism," Quarterly Journal of Economics, Vol. 84, No, 3, pp. 488-500.

2. COMTRADE (2018), Official database, available at: https://comtrade.un.org/db/daBasicQuery.aspx (11 June 2018).

3. Dano, K., Zadrima, F., Bezhani, S., Mine, V. (2008). The methodology of Inventory and the Monitoring of MAPs in District of Elbasan. Tirane: National Agency for the Environment, Document in Albanian.

4. Hoxha, V. (2014), "Quelles méthodes pour la gestion durable de la ressource des plantes aromatiques et médicinales ? Analyse des inventaires historiques en Albanie et modélisation des habitats à partir des traces GPS des cueilleurs en vue de la construction d'un observatoire", Thèse de doctorat, Université Paul Valéry, UM3. 263 p.

5. Hoxha, V. (2016), "Chapter La dynamique des plantes aromatiques et médicinales en Albanie", in lbert, H., Hoxha, V., Sahi, L., Courivaud, A., Chailan, C. (Eds.), Le marché des plantes aromatiques et médicinales: analyse des tendances du marché mondial et des stratégies économiques en Albanie et en Algérie, Montpellier: CIHEAM/FranceAgriMer, Options Méditerranéennes: Série B, Etudes et Recherches 73, pp. 45-98.

6. Hoxha, V., Ilbert, H. (2017), "An alternative methodology based on gatherers and GPS sensors to sustainable management of aromatic and medicinal plants", in Proceedings of EFITA WCCA Congress, Montpellier, France, Montpellier SupAgro, pp. 29-30.

7. Ilbert, H., Hoxha, V. (2016). "Chapter Marché mondial des plantes : analyse des échanges et de la position de l'Albanie et de l'Algérie", in llbert, H., Hoxha, V., Sahi, L., Courivaud, A., Chailan, C. (Eds.), Le marché des plantes aromatiques et médicinales: analyse des tendances du marché mondial et des stratégies économiques en Albanie et en Algérie, Montpellier: CIHEAM/FranceAgriMer, Options Méditerranéennes: Série B. Etudes et Recherches 73, pp.17-40.

8. Kaplinsky, R, Morris, M. (2001), "A Handbook for Value Chain Research", Prepared for the International Development Research Centre (IDRC), Sustainability, UNEP and UN Global Compact, pp. 4-6.

9. Kutrolli, F., Ukaj, J. (2009), Praktika të mira në mbledhjen e bimësisë mjekësore dhe aromatike për sigurimin e qëndrueshmërisë së tyre në zonën e Pukës, Tiranë, 2008, Studim i financuar nga Qeveria Zviceriane nwpwrmjet projektit AGROPUKA, Studim nw shaip.

10. Lekocaj, J., Hoxha, V., Lekaj, P. (2017), The performance and the transparency of MAPs market sector in Albania. The actors' limited rationality identification based on the value chain analysis. The fourth International Conference: The problems and the challenges of the Albanian society transformation toward the EU standards, Tirana, Albania.

11. Llubani, F. (1988), Study about the MAPs inventory. Tirane: [The station of forests, plants' culture and essential oil] Document in Albanian. 
12. Noka, K., Musabelliu, B. (2003), Social and Economic Relevance of NTFPs in Albania, Albanian National Forest Inventory (ANFI) Special Study, USAID project.

13. Paul, B. V. (2014), "Assessing the Medicinal and Aromatic Plants in Albania, Value chain analysis", Centre for International Development, Harvard University, available at: https://albania.growthlab.cid.harvard.edu/files/albaniagrowthlab/files/medicinal_arom atic_plants.pdf? $m=1463423463$ (11 June 2018).

14. Rothschild, M., Stiglitz, J. (1970), "Increasing risk: I. a definition", Journal of Economic Theory, Vol. 2, No. 3, pp. 225-243.

15. USAID (2010), "Albania medicinal and aromatic plants: value chain assessment", Albanian agriculture competitiveness (AAC) programme, Washington: USAID, p. 85, available at: https://pdf.usaid.gov/pdf_docs/PA00JN (11 June 2018).

\section{About the authors}

Julian Lekocaj works as a manager at GFI- Albania Ltd. He is graduated at the Agricultural University of Tirana where he got the MSc degree with the topic "The risk of liquidity for the second level banks in Albania". He is a Ph.D. candidate, and his research activity is focused on the aromatic and medicinal plants value chain, by identifying and analyzing all the involved actors between the links of the MAPs industry. The author can be contacted at julianlekocaj@gmail.com.

Valter Hoxha is a lecturer at the UMT University. He is graduated at Paul-Valéry Institution / UM3 University, Montpellier, France, where he received his Ph.D. with the topic "An alternative methodology based on gatherers and GPS sensors to sustainable management of the aromatic and medicinal plants". His research activity is focused on natural resources management and more specifically in the aromatic and medicinal plants using GPS technology in their identification and evaluation; territorial management and information economy. The author can be contacted at valter.hoxha@umsh.edu.al. 